\title{
Editorial
}

\section{Lucha contra el crimen y democracia}

Es indudable que en El Salvador de la posiguerra, a la par de otras formas de violencia, la violencia delincuencial ha alcanzado niveles alarmantes, mismos que urgen de una respuesta pronta y eficaz por parte de las autoridades. Y esta respuesta involucra, entre otros aspectos, un componente coercitivo que no puede ser soslayado. Si existen grupos e individuos -adiestrados en el manejo de armas de grueso calibre- que están dispuestos a asesinar a sus víctimas para quedarse con sus bienes (sea mediante el robo directo o el secuestro), la respuesta del Estado debe ser contundente en su componente de fuerza.

La señal debe ser clara para todos: nadie que haya optado por la violencia como forma de vida va a ser más fuerte que el Estado, nadie que haya optado por la violencia como método para lucrarse a expensas dé los demás debe creer que la debilidad del Estado lo pone en ventaja para realizar sus fechorías. Ahora bien, es responsabilidad de las autoridades no permitir que en el seno del crimen organizado y no organizado tenga lugar la idea de que el Estado es débil e incapaz de responder con una fuerza mayor a sus acciones violentas. Si la convicción de que el Estado es más fuerte que, por ejemplo, secuestradores y ladrones de bancos no arraiga en el mundo del crimen -es de temer que algo de eso esté pasando ya-, la proliferación de actos delincuenciales será cada vez más inmanejable. Y, en consecuencia, la vida, la seguridad y los bienes de más ciudadanos correrán mayores peligros.

Precisamente, en un orden democrático, el Estado tiene como una de sus finalidades primordiales garantizar la vida, la seguridad y las libertades esencia- 
les de quienes se cobijan bajo sus jurisdicción. Ahora bien, ese compromiso del Estado supone y exige, si es necesario, el uso de la fuerza contra aquéllos que ponen en peligro la vida, la seguridad y las libertades fundamentales de sus ciudadanos. No se trata de un "poner en peligro" teórico; no se trata de que se "sospeche" de las actividades ilícitas de individuos o grupos; lo que debe preocupar a las autoridades son las acciones efectivas de secuestros y asaltos que son realizados por bandas organizadas o semiorganizadas, que cuentan con equipos de comunicación, transporte y armamento sofisticados. El Estado debe proleger - si es preciso usando altas dosis de fuerza- a sus ciudadanos de estas acciones que efectivamente causan muerte, sufrimiento y pérdidas materiales.

Sin embargo, esa protección -la obligación que tiene el Estado de brindarla - no debe convertirse en un pretexto para dotarlo de atribuciones que lo pongan por encima y aun en contra de la sociedad; es decir, para convertir al Eslado en una entidad antidemocrática. Sabemos, por nuestro pasado reciente, lo nefasto que puede sęr que el Estado se convierta en juez último ( $y$ absoluto) de lo que conviene o no conviene a la sociedad. Necesitamos un Estado democrático, no un Estado policial. Necesitamos un Estado que, en el marco del respeto a las reglas y valores esenciales de la democracia, garantice a todos los que respetamos y aceptamos vivir en el marco de esos valores, o no los socavamos violentamente (quien roba, asesina y secuesira como profesión se ha situado fuera de la democracia, aunque ésta le reconozca ciertos derechos), poder vivir en paz $y$ tranquilidad.

No necesitamos un Estado que, so pretexto de defender nuestra vida y propiedades, violente el orden democrático, sospeche de todos y en todo momento, se oriente por presunciones de peligros de cuya autoría pueda ser acusado cualquiera (de preferencia los enemigos políticos), que ordene cateos, requisas y revisión de documentos cada vez que se le antoje al jefe de tumo... Si creemos mínimamente en la democracia debemos decir un no tajante al Estado policial. Necesitamos, eso sí, un Estado dotado de los mecanismos más eficaces y adecuados para combatir la criminalidad en sus más diversas manifestaciones. Y, entre estos mecanismos, la policía desempeña una función de primera importancia.

Todavía no cala en la conciencia de muchos sectores sociales, económicos y políticos la idea de que es necesario un cuerpo policial dotado de los recursos humanos, financieros y tecnológicos que le permitan garantizar la seguridad ciudadana con eficacia. Hay quienes creen que basta con aumentar el número de efectivos policiales o con dolarlos de mayor poder de fuego para que el crimen disminuya. Esto, sin dejar de ser relevante, no es suficiente; se requiere, además, de policías con adecuados niveles de educación en el respeto a los derechos humanos y con las competencias suficientes en el manejo de las tecnologías más sofisticadas para el combale de la criminalidad. Sin duda alguna, este último punto reviste especial importancia, pues en la medida que las capacidades y 
recursos tecnológicos de la policía estén por debajo de las que tienen a su disposición los criminales - por ejemplo, en materia de comunicaciones, transporte y armamentos- éstos tendrán a todas luces las mayores ventajas.

Con una policía competente, bien entrenada, respetuosa de los derechos humanos y decidida, con la dureza y determinación del caso, a combatir el crimen se hace innecesaria la utilización de ese otro recurso de coerción estatal, como lo es el ejército. Los que han clamado y claman por la salida del ejército a las calles no deben obviar los peligros que para la instauración democrática puede traer una militarización de la sociedad. En la década pasada tuvimos bastante de patrullajes y puestos militares en bartios y colonias; como efecto colateral de ello tuvimos abusos de autoridad, maltratos e intimidación. No es sano abrir la posibilidad, por muy remota que pueda parecer, de que los militares puedan controlar nuevamente a la sociedad.

La lucha contra el crimen y la conservación de la democracia no son excluyentes, sino todo lo contrario. Defender la idea de que para combatir la criminalidad es necesario violentar el Estado de derecho es apostar por prácticas autoritarias que, en el momento menos esperado, terminan revirtiéndose contra sus propugnadores. 